\title{
Acute Diarrhea in Children Less than Five Years of Age: Epidemiology of Bacterial Pathogens
}

\author{
Florence Salvatory Kalabamu, Pauline Lukumo Mpongo, Esther Mwaikambo \\ Hubert Kairuki Memorial University, Dar es salaam, Tanzania
}

\begin{abstract}
Objectives: Acute diarrhea is among the leading causes of mortality and morbidity worldwide. Bacteria tend to cause more fatal illnesses and complications such as septicemia and persistent diarrhea. This study aimed to determine the causes of acute diarrhea, laboratory and clinical predictors of bacterial causes, and antimicrobial resistance pattern among the isolates among children in Dar es salaam, Tanzania.

Methods: A cross-sectional hospital-based study was conducted in Dar es salaam Hospitals from April 2015 to March 2016 among children below five years of age who presented with acute diarrhea. Demographic characteristics and results from stool specimen analysis, complete blood count, C- reactive protein and antimicrobial resistance results were recorded using a pre-structured clinical research form

Results: Among 200 children enrolled, viruses were identified in $149(74.5 \%)$ of the cases. Bacterial pathogens were found in $15(7.5 \%)$ cases only. Elevated stool red blood cell count, stool white blood cell count, and fever were highly associated with enteric bacterial pathogens $(p<0.001, p=0.002$ and $p=0.04$ respectively). Most of the bacterial isolates were resistant to Cotrimoxazole and erythromycin but highly sensitive to ciprofloxacin and Ceftriaxone.

Conclusion: Fever, elevated stool leukocyte and elevated stool red blood cells are significant predictors of bacterial enteric pathogens in children with acute diarrhea. These parameters may guide clinicians in resource-limited settings in the diagnosis and management of acute diarrhea. Further studies should be conducted to determine local antimicrobial resistance patterns. J Microbiol Infect Dis 2020; 10(3): 208-214.
\end{abstract}

Keywords: Acute diarrhea, causes, predictors, antimicrobial resistance, children

\section{INTRODUCTION}

Diarrhea is the second cause of mortality among children under five years of age worldwide preceded by neonatal complications. It is estimated that around 2.5 billion diarrhea cases occur per year worldwide with $50 \%$ of these cases in Africa and South Asia. Among these cases, 1.5 million die with $85 \%$ of death taking place in Africa $[1,2]$

The most common causes of diarrhea in children are viruses, bacteria, and other parasites but these vary from one region to another [3-6]. Studies were done in Dar es salaam and Ifakara in Tanzania demonstrated variations in these pathogens depending on age, location (rural or urban) and seasons (rainy or dry) $[3,7,8]$. The most common pathogens were Escherichia coli, Cryptosporidium parvum, Shigella spp, Rotavirus, and Giardia lamblia.
Diarrheal diseases are transmitted by fecal-oral route with the major risk factors for transmission being an inadequate supply of safe water, poor sanitation and hygiene $[1,2]$.

Clinical presentation of acute diarrhea is almost the same regardless of the etiology. These features may include acute onset of passing loose stool more than three times in 24 hours, fever, vomiting, abdominal clumps and dehydration. Bloody diarrhea may be present in the case of enteroinvasive organisms [9]. Most of diarrhea cases resolve spontaneously or by supportive rehydration and zinc supplementation [9]. Systemic antibiotics are warranted in case of life-threatening bacterial infections such as enteroinvasive E. coli, Shigella spp or cholera $[9,10]$. If not well treated, bacterial pathogens may lead to disseminated infection such as septicemia, meningitis, pneumonia and subsequently death [11-14] 
World Health Organization (WHO) recommends the use of antibiotics such as ciprofloxacin and ceftriaxone [9] in case of dysentery due to suspected shigellosis but deaths have been reported in other non-dysenteric shigella and other enteric bacterial pathogens which do not present with bloody diarrhea $[5,11,14,15]$.

It is usually difficult to differentiate bacterial diarrhea from other pathogens by using clinical signs and symptoms. Standard confirmatory tests of etiologies are usually not available in resource-poor countries and some of them are expensive to perform. This may lead to delayed diagnosis and inappropriate management of children with bacterial diarrhea leading to complications and death.

This study aimed to determine the causes, clinical and routine laboratory test which may predict bacterial etiology in children with acute diarrhea and antimicrobial sensitivity pattern among the bacterial isolates. If these children are identified early and specific confirmatory tests done, it may reduce the diagnostic costs of testing every child with diarrhea and may also guide clinicians on the appropriate management of children with suspected enteric bacterial pathogens.

\section{METHODS}

\section{Study site and design}

A cross-sectional hospital-based study was conducted at Temeke, Amana and Mwananyamala Hospitals in Dar es Salaam from April 2015 to March 2016. Children below five years of age with acute diarrhea attending inpatient and outpatient services were enrolled in the study. Those who were on antibiotics, or had a known history of food intolerance, or persistent diarrhea for more than 14 days were not included.

\section{Ethical issues}

Ethical clearance was obtained from the Ethical Review Committee (ERC) of the Hubert Kairuki University followed by permissions form the respective municipal authorities and hospitals.

After the informed consent process, social demographic information and clinical evaluation of the participants and study specimen collection were done. Data were recorded on a pretested clinical research form.
Study sample collection, transport, and analysis

Blood and stool samples were collected and according to the current protocols [16] and then transported the central research laboratory at Hubert Kairuki Memorial University for analysis. Complete blood count and differentials were performed (Beckman-Coulter, Model Act 10) as well as C-Reactive protein using standard technique (SYNCHRON CX®, BeckmanCoulter, 2008).

Stool microscopy analysis using wet preparations was performed to detect stool red and white blood cells, protozoa cysts, and helminths ova. Bacterial pathogens were identified in stool samples as described in the Clinical and Laboratory Standard Institute Guidelines as described in other similar studies $[3,10]$. The disc diffusion method was used to determine the antimicrobial sensitivity of bacterial isolates (CLSI,2006). Antibiotics tested were co-trimoxazole, Erythromycin, ciprofloxacin, Gentamicin, and Ceftriaxone. Rapid immunochromatographic tests for the detection of viral antigens were used to detect rotavirus, adenovirus, norovirus, and astrovirus (Ridaquick, Generic Assays, 2014).

\section{Data analysis}

Data were analyzed using Statistical Package for Social Sciences for Windows (SPSS Version 20). Proportions and categorical variables were compared using the Chi-square test. Binary logistic regression analysis was used to determine the clinical and laboratory predictors of bacterial causes of diarrhea. A p-value of less than 0.05 was considered statistically significant.

\section{RESULTS}

A total of 200 participants were recruited in the study. Males were $125(62.5 \%)$ while females were $75(37.5 \%)$. Most of the participants (92.5\%) presented with diarrhea for less than 5 days. On presentation, 134 (66\%) children had no dehydration, $63(31 \%)$ had some dehydration while only $3(1.5 \%)$ had severe dehydration. Other baseline characteristics are shown in Table 1.

Viruses comprised the major causes of diarrhea. Viral causes were identified in $149(74.5 \%)$ of the study participants. Rotavirus was responsible for 84 cases 
(42\%) followed by adenovirus (29\%) and norovirus (3.5\%). Astrovirus was not detected (Figure 1).

Table 1. Baseline characteristics of participants

\begin{tabular}{ll}
\hline Variable & No. of Cases (\%) \\
\hline Hydration status & \\
Normal & $134(66.0)$ \\
Some dehydration & $63(31.0)$ \\
Severe dehydration & $3(1.5)$ \\
Total & $200(100)$
\end{tabular}

\section{Gender}

$\begin{array}{ll}\text { Male } & 125(62.5) \\ \text { Female } & 75(37.5) \\ \text { Total } & 200(100)\end{array}$

\begin{tabular}{|c|c|}
\hline Age & \\
\hline less than 2 years & $168(84)$ \\
\hline more than 2 years & $32(16)$ \\
\hline Total & $200(100)$ \\
\hline
\end{tabular}

Body temperature

$\begin{array}{ll}\text { No fever }\left(<37.5{ }^{0} \mathrm{C}\right) & 177(88.5) \\ \text { With fever } & 23(11.5) \\ \text { Total } & 200(100)\end{array}$

$\begin{array}{ll}\text { Bodyweight } & \\ \text { below } 10 \mathrm{~kg} & 133(66.5) \\ \text { between } 10-20 \mathrm{~kg} & 66(33) \\ \text { above } 20 \mathrm{~kg} & 1(0.5) \\ \text { Total } & 200(100)\end{array}$

\section{Duration of Diarrhea}

$\begin{array}{ll}\text { less than } 5 \text { days } & 185(92.5) \\ \text { between } 5-10 \text { days } & 15(7.50) \\ \text { more than } 10 \text { days } & 0(0) \\ \text { Total } & 200(100)\end{array}$

Bacteria were isolated in 15 stool samples only $(7.5 \%)$. Pathogens isolated were Escherichia coli [7(46.7\%)], Salmonella typhii [3(20\%)], Shigella dysenteriae [3(20\%)]. Vibrio cholerae was isolated in 2 cases (13.3\%) as shown in figure 2. Other pathogens were Amoeba histolytica 10 (5\%) and intestinal worms 10(5\%).
There were no specific findings in 16 (8\%) of the stool samples. Most of the bacterial pathogen isolates were resistant to Cotrimoxazole and highly sensitive to Ciprofloxacin and Ceftriaxone (Table 2).

The presence of red blood cells in stool was found to be highly associated with bacterial causes of diarrhea $[\mathrm{OR}=50.7, \mathrm{Cl}=8.7-296.7$ $(\mathrm{P}<0.001)]$. Other factors found to be associated with enteric bacterial pathogens were elevated white blood cells in stool $[\mathrm{OR}=42.9$, $\mathrm{Cl}=1.8-1026(\mathrm{P}=0.02)]$ and presence of fever with body temperature $>37.5{ }^{0} \mathrm{C} \quad[\mathrm{OR}=7$, $\mathrm{Cl}=1.1-47(\mathrm{P}=0.04)]$. Age, elevated total white blood count, and C-reactive proteins were not significantly associated with bacterial causes of diarrhea (Table 3).

\section{DISCUSSION}

Enteric pathogens were found in 186 (92\%) of stool specimens from children with acute diarrhea who participated in our study. This is higher compared with other studies that were done in Dar es Salaam and Ifakara whereby enteric pathogens were found only in $67.1 \%$ and $71.8 \%$ of the stool samples collected respectively $[3,7]$. High yield in our study could be because other studies did not investigate other enteric pathogens than bacteria and viruses. In our study we also excluded children with persistent diarrhea, and who had a previous history of antibiotic use during the index illness.

We found that viruses were the most common pathogens (rotavirus, adenovirus, and norovirus) compared to other pathogens. This slightly varies from other studies in Tanzania whereby bacterial pathogens were commonly isolated. A study done by Moyo et al in Dar es salaam found the bacterial causes to be $33.2 \%$ with Escherichia spp leading followed by Shigella spp [3]. Another study done by Vargas and others in Ifakara demonstrated that bacteria were the most common pathogens with Escherichia spp leading (35.7\%), followed by rotavirus (23\%) [7]. Our findings are similar to these studies by showing that Escherichia spp are the most common bacterial pathogens in stool samples of children with diarrhea $[4,7,17]$. This is also consistent with other findings in different parts of the world showing the major three causes of diarrhea to be rotavirus, Escherichia spp, and Shigella spp [18-22]. 
Table 2: Antimicrobial sensitivity pattern among the enteric bacterial pathogens isolated in stool of children with acute diarrhea.

\begin{tabular}{lcccc}
\hline Antimicrobial agent & $\begin{array}{c}\text { Escherichia spp } \\
(\mathrm{n}=7)\end{array}$ & $\begin{array}{c}\text { Shigella spp } \\
(\mathrm{n}=3)\end{array}$ & $\begin{array}{c}\text { Salmonella spp } \\
(\mathrm{n}=3)\end{array}$ & $\begin{array}{c}\text { Cholera spp } \\
(\mathrm{n}=2)\end{array}$ \\
\hline Cotrimoxazole & $0 \%$ & $33 \%$ & $0 \%$ & $0 \%$ \\
\hline Erythromycin & $45 \%$ & $0 \%$ & $0 \%$ & $0 \%$ \\
\hline Ciprofloxacin & $91 \%$ & $100 \%$ & $100 \%$ & $50 \%$ \\
\hline Gentamicin & $45.5 \%$ & $0 \%$ & $0 \%$ & $10 \%$ \\
Ceftriaxone & $100 \%$ & $100 \%$ & $100 \%$ & $100 \%$ \\
\hline
\end{tabular}

Table 3. Clinical and laboratory features associated with bacterial causes of acute diarrhea.

\begin{tabular}{|c|c|c|c|c|c|}
\hline Variable & $\begin{array}{c}\text { Number } \\
\text { Bacteria isolated }\end{array}$ & $\begin{array}{l}\text { No. of bacteria } \\
\text { isolated }\end{array}$ & AOR & $\begin{array}{c}95 \% \text { confidence } \\
\text { interval }\end{array}$ & P Value \\
\hline $\begin{array}{l}\text { Age(years) } \\
\leq 2 \text { Years } \\
>2 \text { years }\end{array}$ & $\begin{array}{l}7(4.2 \%) \\
8(25 \%)\end{array}$ & $\begin{array}{c}160(95.8 \%) \\
24(75 \%)\end{array}$ & 1.835 & $.218-15.411$ & .576 \\
\hline $\begin{array}{l}\text { Body Temperature }\left(\mathrm{C}^{\circ}\right) \\
\text { No fever } \\
\text { With fever }\left(>37.5^{\circ} \mathrm{C}\right)\end{array}$ & $\begin{array}{l}7(46.7 \%) \\
8(53.3 \%)\end{array}$ & $\begin{array}{c}169(91.8 \%) \\
15(8.2 \%)\end{array}$ & 7.104 & $1.071-47.108$ & $.042^{*}$ \\
\hline $\begin{array}{l}\text { Total white blood cell count } \\
\text { Normal }(<12,000 / \mu l) \\
\text { Significantly elevated }\end{array}$ & $\begin{array}{l}7(46.7 \%) \\
8(53.3 \%)\end{array}$ & $\begin{array}{c}123(68 \%) \\
56(32 \%)\end{array}$ & .848 & $.151-4.776$ & .852 \\
\hline $\begin{array}{l}\text { Stool red blood cells(/HPF) } \\
\text { Normal(<5rbc/hpf) } \\
\text { Significantly elevated }\end{array}$ & $\begin{array}{c}4(26.7 \%) \\
11(73.3 \%)\end{array}$ & $\begin{array}{c}176(92.2 \%) \\
7(3.8)\end{array}$ & 50.712 & $8.667-296.730$ & $.000^{*}$ \\
\hline $\begin{array}{l}\text { Stool Leucocytes (HPF) } \\
\text { Normal (<10wbc/hpf) } \\
\text { Significantly elevated }\end{array}$ & $\begin{array}{c}4(26.7 \%) \\
11(73.3 \%)\end{array}$ & $\begin{array}{c}182(99.5 \%) \\
1(0.5 \%)\end{array}$ & 42.952 & $1.797-1026.383$ & $.020^{*}$ \\
\hline $\begin{array}{l}\text { C-Reactive protein (CRP) } \\
\text { Normal } \\
\text { Significantly elevated (>6 gm/L) }\end{array}$ & $\begin{array}{l}9(64.4 \%) \\
5(35.7 \%)\end{array}$ & $\begin{array}{c}165(90.2 \%) \\
18(9.8 \%)\end{array}$ & 3.066 & $0.415-22.677$ & .272 \\
\hline
\end{tabular}

\section{AOR=Adjusted Odd Ratio}

We found that fever was among the significant predictors of bacterial diarrhea among the study participants. These findings are consistent with other studies done elsewhere [21-25]. This could be because most of the bacterial pathogens cause more severe inflammation with more severe systemic response compared to viruses and other less virulent pathogens. 
Another significant predictor was the presence of blood or red blood cells in stool analysis. This is consistent to most of other research finding [22-27]. This is the result of the destruction of the intestinal lining through different mechanisms. Some bacteria such as Shigella spp cause damage by directly invading the intestinal mucosa (entero-invasive) while others such as Shiga like toxin-producing $E$. coli cause damage by producing toxins that destroy the integrity of the luminal wall leading to either macro or micro bleeding [28].The presence of red blood cells in the stool may not be used to predict the presence of other pathogenic bacteria that cause secretory diarrhea by producing enterotoxins that interact with multiple ion and solute transporters across the intestinal epithelium such as cholera and enterotoxigenic E. coli [29].

Elevated stool leukocyte was significantly associated with the presence of bacterial pathogens. Most of the other researchers have also demonstrated this whereby elevated stool leukocyte above 10/high power field was highly predictive of bacterial diarrhea [26,30-32]. Other studies have further demonstrated that invasive bacterial pathogens such as Shigella spp have a more inflammatory response with elevated stool leukocyte compared to non-invasive organisms such as Cholera spp.

Abdominal pain was not among the predictors of bacterial pathogens in our study. This is contrary to the general belief and findings from other studies that have shown abdominal cramps to be among the indicators of bacterial enteric pathogens $[25,33]$. Because the majority of our study participants were children below 2 years of age, probably it was difficult for parents to tell if they were crying because of abdominal pain or something else.

In our study, we could not find any relationship between elevated serum C-Reactive Protein (CRP) and the presence of bacterial pathogens. Other studies have demonstrated moderate sensitivity and specificity of CRP in distinguishing bacterial from other causes of diarrhea in children $[30,34,35]$ but compared to our study, in these studies, the CRP cut off point values were set much higher to give significant results.
Most of the bacterial isolates were resistant to commonly used antibiotics such as erythromycin and co-trimoxazole but sensitive to ciprofloxacin and ceftriaxone. Although the number of bacterial cases was not enough to generalize the results, it conforms with the current trend of microbial resistance to the commonly used antibiotics, which has been demonstrated by other studies in Tanzania $[3,17]$. This could be due to the irrational use of antibiotics during the management of infections whereby these antibiotics are prescribed even in the absence of convincing evidence for the presence of bacterial infections.

In conclusion, fever, elevated stool leukocyte, and elevated stool red blood cells are significant predictors of bacterial enteric pathogens in children with acute diarrhea. These parameters may be used by clinicians in a resource-limited setting, either to provide supportive treatment for diarrhea or perform further confirmatory tests such as blood culture do identify the etiology and provide appropriate treatment. Further studies should be conducted to determine local antimicrobial resistance patterns, and establish functional antimicrobial stewardship bodies.

\section{ACKNOWLEDGMENTS}

We are highly indebted to children and parents who participated in the study. We also acknowledge the support from Kinondoni, Ilala and Temeke Municipal councils as well as Amana, Mwananyamala and Kairuki Hospitals for their permission to conduct the study in their hospitals. We also appreciated the laboratory work done by Stephen Biginagwa and Irene Maokola for data entry

Declaration of Conflicting Interests: The authors declare that they have no conflict of interest.

Funding: We also acknowledge the support from the Medical Education Partnership Initiative for funding our study.

\section{REFERENCES}

1. WHO, UNICEF. Diarrhoea: why children are still dying and what can be done. WHO 2010; 375(9718).

2. Black RE, Morris SS, Bryce J. Where and why are 10 million children dying every year? Lancet 2003; 361(9376):2226-2234.

3. Moyo SJ. Age specific aetiological agents of diarrhoea in hospitalized children aged less than 
five years in Dar es Salaam, Tanzania. BMC Pediatr 2011; 11(3): 19.

4. Moyo SJ, Maselle SY, Matee MI, Langeland N, Mylvaganam $\mathrm{H}$. Identification of diarrheagenic escherichia coli isolated from infants and children in Dar es Salaam, Tanzania. BMC Infect Dis 2007; 7:1-7.

5. Nair GB. Emerging trends in the etiology of enteric pathogens as evidenced from an active surveillance of hospitalized diarrhoeal patients in Kolkata, India. Gut Pathog 2010; 2 (1):1-13.

6. Liu J, Platts-Mills JA, Juma.J, et al. Use of quantitative molecular diagnostic methods to identify causes of diarrhoea in children: a reanalysis of the GEMS case-control study. Lancet 2016; 388(10051):1291-301.

7. Vargas M. Etiology of diarrhea in children less than five years of age in Ifakara, Tanzania. Am J Trop Med Hyg 2004; 70(5):536-539.

8. Ruiz J. Etiology of Diarrhea in Children Less Than Five Years of Age in Ifakara, Tanzania. Am J Trop Med Hyg 2018; 70(5): 536-539.

9. WHO. Pocket book of hospital care for children, Guideline for the management of the common childhood illnesses, 2nd edn. Geneva: WHO, 2013: 142-143.

10. Shane AL. Infectious Diseases Society of America Clinical Practice Guidelines for the Diagnosis and Management of Infectious Diarrhea. Clin Infect Dis 2017; 65(12): e45-e80.

11. Talbert A. Mortality after inpatient treatment for diarrhea in children: A cohort study. BMC Med 2019;17(1): 1-11.

12. Afroze F. Risk factors and outcome of Shigella encephalopathy in Bangladeshi children. PLoS Negl. Trop. Dis 2017;11(4): 1-11.

13. Tickell KD, Brander RL, Atlas HE, Pernica JM, Walson JL, Pavlinac PB. Identification and management of Shigella infection in children with diarrhoea: a systematic review and meta-analysis. Lancet Glob Health 2017; 5(12): e1235-e1248.

14. Troeger C. Estimates of the global, regional, and national morbidity, mortality, and aetiologies of diarrhoea in 195 countries: a systematic analysis for the Global Burden of Disease Study 2016. Lancet Infect. Dis 2018; 18(11):1211-1228.

15. O'Reilly CE, Jaron $P$, Ochieng $B$, et al. Risk factors for death among children less than 5 years old hospitalized with diarrhea in rural Western Kenya, 2005-2007: A cohort study. PLoS Med 2012; 9(7):2005-2007.

16. World Health Organization. Foodborne disease outbreaks: guidelines for investigation and control. Geneva: World Health Organization, 2008.
17. Moremi N, Othman AS, Msaki BP, Mshana SE. Prevalence and antimicrobial sensitivity of shigatoxin-producing Escherichia coli among underfives presenting with diarrhoea at hospitals in Mwanza city, Tanzania. Tanzan J Health Res 2017; 191-6

18. Pernica JM, Steenhoff AP, Welch $H$, et al. Correlation of clinical outcomes with multiplex molecular testing of stool from children admitted to hospital with gastroenteritis in Botswana. J Pediatric Infect Dis Soc 2016;5(3): 312-318.

19. Cooke ML. Causes and management of diarrhoea in children in a clinical setting. South African J Clin Nutr 2010; 23(1): 42-46.

20. Radlović N, Leković Z, Vuletić B, Radlović V, Simić D. Acute diarrhea in children. Srp Arh Celok Lek 2015; 143(11):755-762.

21. Feleke H, Medhin G, Abebe A, Beyene B, Kloos $H$, Asrat D. Enteric pathogens and associated risk factors among under-five children with and without diarrhea in Wegera district, northwestern Ethiopia. Pan Afr Med J 2018; 29:1-10.

22. Elliott EJ. Clinical Review Acute gastroenteritis in children. Br Med J 2007; 334: 35-40.

23. Finkelstein JA, Schwartz JS, Torrey S, Fleisher GR. Common clinical features as predictors of bacterial diarrhea in infants. Am. J. Emerg. Med 1989; 7(5): 469-473.

24. Wiegering $V$, Kaiser J, Tappe D, Weißbrich B, Morbach $H$, Girschick $H$. Gastroenteritis in childhood: A retrospective study of 650 hospitalized pediatric patients. Int $\mathrm{J}$ Infect Dis 2011;15(6): e401-e407.

25. Al-Marzoki JM. Clinical and laboratory predictors of acute bacteria diarrhoea. JABHS 2009; 10(2): 2-7. http://arabboard.org/sites/default/files/Vol.10\%20No.2.compr essed.pdf

26. Gill CJ, Lau J, Gorbach SL, Hamer DH. Diagnostic Accuracy of Stool Assays for Inflammatory Bacterial Gastroenteritis in Developed and Resource-Poor Countries. Clin Infect Dis 2003; 37(3):365-375.

27. Ascher DP, Ednsada-Corpus R. Clinical and Laboratory Predictors of Bacterial Diarrhea in a Tropical Environment. Mil Med 1991;156(2):7476.

28. Baker S, Hao Chung The. Recent insights into Shigella. Curr Opin Infect Dis 2018; 31(5):, 449454.

29. Thiagarajah JR, Donowitz M, Verkman AS. Secretory diarrhoea: Mechanisms and emerging therapies. Nat. Rev. Gastroenterol. Hepatol 2015;12(8):446-457.

30. Shim DH, Kim DY, Cho KY. Diagnostic value of the Vesikari Scoring System for predicting the viral 
or bacterial pathogens in pediatric gastroenteritis. Korean J. Pediatr 2016; 59(3):126-131.

31. Cheng AC, McDonald JR, Thielman NM. Infectious diarrhea in developed and developing countries. J Clin Gastroenterol 2005; 39(9):757773.

32. Mercado EH. Fecal leukocytes in children infected with diarrheagenic escherichia coli. J Clin Microbiol 2011; 49(4):1376-1381.

33. McKee RS, Tarr PI, Dietzen DJ, Chawla R, Schnadower D. Clinical and Laboratory Predictors of Shiga Toxin-Producing Escherichia coli Infection in Children with Bloody Diarrhea. J. Pediatric Infect. Dis. Soc 2018;7(3):e116-e122.

34. Borgnolo G, Barbone F, Guidobaldi G, Olivo G. C-reactive protein in viral and bacterial gastroenteritis in childhood. Acta Paediatr Int $\mathrm{J}$ Paediatr 1996; 85(6): 670-674.

35. Marcus M, Mor M, Amir L, Mimouni M, Waisman Y. The Quick-Read C-reactive protein test for the prediction of bacterial gastroenteritis in the pediatric emergency department. Pediatr Emerg Care 2007; 23(9): 634-637. 